\title{
Can Social Inclusion Policies Reduce Health Inequalities in Sub-Saharan Africa?-A Rapid Policy Appraisal
}

\author{
Laetitia C. Rispel', César A.D. Palha de Sousa², and Boitumelo G. Molomo³ \\ 'Centre for Health Policy, School of Public Health, University of the Witwatersrand, Johannesburg, South Africa, \\ ${ }^{2}$ Department of Community Health, Faculty of Medicine, Eduardo Mondlane University, Maputo, Mozambique, \\ and ${ }^{3}$ ESKOM Holdings (Ltd.), Johannesburg, South Africa
}

\begin{abstract}
The global resurgence of interest in the social determinants of health provides an opportunity for determined action on unacceptable and unjust health inequalities that exist within and between countries. This paper reviews three categories of social inclusion policies: cash-transfers; free social services; and specific institutional arrangements for programme integration in six selected countries-Botswana, Mozambique, South Africa, Ethiopia, Nigeria, and Zimbabwe. The policies were appraised as part of the Social Exclusion Knowledge Network (SEKN) set up under the auspices of the World Health Organization's Commission on Social Determinants of Health. The paper highlights the development landscape in sub-Saharan Africa and presents available indicators of the scale of inequity in the six countries. A summary of the policies appraised is presented, including whether or what the impact of these policies has been on health inequalities. Crosscutting benefits include poverty alleviation, notably among vulnerable children and youths, improved economic opportunities for disadvantaged households, reduction in access barriers to social services, and improved nutrition intake. The impact of these benefits, and hence the policies, on health status can only be inferred. Among the policies reviewed, weaknesses or constraints were in design and implementation. The policy design weaknesses include targeting criteria, their enforcement and latent costs, inadequate participation of the community and failure to take the cultural context into account. A major weakness of most policies was the lack of a monitoring and evaluation system, with clear indicators that incorporate system responsiveness. The policy implementation weaknesses include uneven regional implementation with rural areas worst affected; inadequate or poor administrative and implementation capacity; insufficient resources; problems of fraud and corruption; and lack of involvement of civil servants, exacerbating implementation capacity problems. The key messages to sub-Saharan African governments include: health inequalities must be measured; social policies must be carefully designed and effectively implemented addressing the constraints identified; monitoring and evaluation systems need improvement; and participation of the community needs to be encouraged through conducive and enabling environments. There is a need for a strong movement by civil society to address health inequalities and to hold governments accountable for improved health and reduced health inequalities.
\end{abstract}

Key words: Health inequalities; Social Exclusion Knowledge Network; Social inclusion; Sub-Saharan Africa

\section{INTRODUCTION}

"A child born in Africa faces more health risks than a child born in other parts of the world. Such a

Correspondence and reprint requests should be addressed to:

Prof. Laetitia Rispel

Private Bag 3, Wits

Johannesburg 2050

South Africa

Email: laetitia.rispel@wits.ac.za

Fax: +27-11-717 3429 child has more than a 50\% chance of being malnourished, a high risk of being HIV-positive at birth while malaria, diarrhoeal diseases, and acute respiratory infections account for $51 \%$ of deaths. A child born in the African region is more likely to lose his/ her mother due to complications in childbirth or HIV/AIDS while that child has a life-expectancy of just 47 years and is very likely-at least once in his/ her short life-to be affected by drought, famine, flood or civil war, or become a refugee" (1).

Sub-Saharan Africa remains the world's poorest 
region with almost half of its people living on less than one dollar a day (2,3). Sub-Saharan Africa also bears the brunt of global health inequalities, with high levels of undernutrition, $50 \%$ of maternal and child deaths, and a high burden of infectious diseases, including HIV and AIDS, malaria, and tuberculosis $(1,3)$.

The growing global interest in the social determinants of health provides an opportunity for determined action on unacceptable and unjust health inequalities that exist within and between countries (4). This paper presents a rapid appraisal of policies, programmes, or actions that have the potential to address social exclusion and reduce health inequalities in six selected countries: Botswana, Mozambique, South Africa, Ethiopia, Nigeria, and Zimbabwe. The term 'health inequalities' refers to the systematic and unfair differences in health experience or outcomes between different socioeconomic groups within or between societies or countries. The paper draws on the research conducted by the Social Exclusion Knowledge Network (SEKN), one of nine global knowledge networks, set up to support the work of the World Health Organization's (WHO's) Commission on Social Determinants of Health (CSDH).

In the first part of the paper, we use the model of social exclusion developed by the SEKN to outline the approach to, and the limitations of, the appraisal of policies. In the second section of the paper, we briefly describe the policies selected for appraisal and whether or what the impact of these policies has been on health inequalities. The factors that enable and hinder the implementation of the policies were also analyzed. The conclusion contains key messages to governments and civil society in sub-Saharan Africa on steps that can be taken to support the global goal of improving health and reducing health inequalities.

\section{Approach to appraisal of policies}

The social exclusion concept has become central to the policy and academic discourse in the European Union and Canada in the last two decades $(5,6)$. However, social exclusion is a problematic concept in sub-Saharan Africa as the majority of people live in poverty. Alternative discourses of poverty, marginalization, vulnerability, and sustainable development continue to have more policy leverage and have received much critical attention. Nevertheless, the notion of social exclusion appears increasingly in African declarations on the 'developmental state' and in-country anti-poverty programmes (7-9).
Given the contested nature of the concept, the SEKN proposed a relational understanding of social exclusion that focuses on processes driving inequalities in health and other domains of life, rather than a static approach focusing on arbitrary lists of variables or particular groups of 'excluded' people (6). The SEKN's definition of social exclusion is given below:

"Exclusion consists of dynamic, multi-dimensional processes driven by unequal power relationships. These operate along and interact across four dimensions-cultural, economic, political and social-and at different levels, including individuals, groups, households, communities, countries and global regions. Exclusionary processes contribute to health inequalities by creating a continuum of inclusion/exclusion. This continuum is characterized by an unjust distribution of resources and unequal capabilities and rights required to:

- Create the conditions necessary for entire populations to meet and exceed basic needs

- Enable participatory and cohesive social systems

- Value diversity

- Guarantee peace and human rights

- Sustain environmental systems" (6).

A rapid appraisal of policies and actions aimed at addressing the relational processes generating social exclusion and health disadvantage was conducted in 2007 as part of the work of the SEKN (10). The appraisal included policies or actions by international agencies, national and local governments, and non-governmental organizations (NGOs), in addressing exclusionary practices. The appraisal complemented other SEKN work strands in sub-Saharan Africa, which included a literature review on social exclusion and proxy concepts of marginalization, vulnerability, and poverty and the associations between exclusionary processes and health disadvantage, key-informant interviews, and a South African country case study. The research ethics committee of the South African Human Sciences Research Council approved the country case study protocol.

The initial intention was to include only those policies with an explicit focus on, or mention of, social exclusion/inclusion. However, globally, and particularly in sub-Saharan Africa, few (if any) policies and actions are explicitly described as addressing 
social exclusion. The above SEKN's definition of social exclusion was used for guiding the inclusion of policies or actions (6). Other selection criteria included: policies that reflect diverse country experiences from Southern, East and West Africa; availability of relevant documentation; and potential for comparative analysis across the SEKN regions.

Given the time constraints, the policies and actions selected in countries other than South Africa and Mozambique were evaluated through a literature review. In South Africa and Mozambique, the appraisal of the policies was complemented by indepth key-informant interviews and the authors' personal knowledge of these countries. The appraisal used a standard framework that sought to:

- describe the policy or action and the country context in which it was being introduced; the intention or objectives of the policy and the target population or beneficiaries;

- determine the factors that supported or constrained the development and/or implementation of the policy/action; and

- review evidence of the intended or unintended impact of the policy/action on social exclusion/inclusion and, if available, on population health/health inequalities.

The policies and actions presented are neither representative nor exhaustive of all potentiallyrelevant actions in sub-Saharan Africa. Nevertheless, the appraisal of the policies provides important insights and contributes to the global debates and imperative to find solutions to unacceptable health inequalities.

\section{SOCIAL INCLUSION POLICIES AND HEALTH INEQUALITIES: REMEDY OR PARADOX?}

Table 1 shows trends in the human development index (HDI) and other key indicators for the six countries that constitute the focus of the appraisal of the policies (3).

The Gini index illustrates the huge income inequalities in Botswana and South Africa compared to Ethiopia, with the lowest per-capita income of the six countries (3). It has been argued that subSaharan Africa, despite the low levels of per-capita income, is one of the most unequal regions in the world (11). Non-income dimensions of inequalities also differ markedly by gender and between rural and urban areas (11). Available information for Ethiopia, Nigeria, South Africa, and Zimbabwe shows stark differences in maternal and childhealth indicators between the poorest $20 \%$ and the richest $20 \%$ of the population (3).

The policies appraised in the six countries are shown in Table 2 and fall into three broad categories: cash-transfers, i.e. money given to certain groups/beneficiaries that meet certain eligibility criteria (12-14); free social services, i.e. free at the point of contact (15-17); and specific programmes or institutional arrangements to ensure programme integration and improved effectiveness of policy outcomes or implementation (18-20).

\section{Cash-transfers}

Cash-transfer programmes are not a new form of social assistance in sub-Saharan Africa but unlike in Latin America where conditional programmes have been widely described (21-23), the programmes in Ethiopia, Mozambique, and South Africa are unconditional, albeit means-tested and dependent on meeting eligibility criteria.

The Productive Safety Net Programme (PSNP) of Ethiopia consists of direct support, i.e. grants to households that are labour-poor and cannot undertake public works, and grants to households whose adults participate in public works projects $(12,24)$. Beneficiaries include orphans, pregnant and lactating mothers, elderly households, and other labour-poor, high-risk households with sick individuals, such as people living with HIV and AIDS, and the majority of female-headed households with young children $(12,24)$. In Ethiopia, reviews of PSNP implementation have shown that several positive changes have taken place in the study areas in terms of nutrition, attitudes, and risk-taking behaviour $(25,26)$. Beneficiaries are reportedly eating better-quality and more food and no longer sell food to pay for short-term household needs, such as medicines or school-fees $(25,26)$. Cash-transfers have also enabled more investment in household livelihood activities and enhanced asset-building in targeted communities (26).

In Mozambique, the cash-transfer programme, also known as a 'food subsidy', is a monthly cash-transfer to extremely poor citizens to ease the combined negative effects of war, natural disasters, and the structural adjustment programme (13). The grant targets women-headed households with five or more children and no other person of working age living in the same household, persons with disabilities, elderly persons, children under difficult conditions, such as orphans, street children, victims of 


\begin{tabular}{|c|c|c|c|c|c|c|}
\hline \multirow{2}{*}{ Indicator } & \multicolumn{4}{|c|}{ Southern Africa } & \multirow{2}{*}{$\begin{array}{c}\text { East } \\
\text { Africa } \\
\begin{array}{c}\text { Ethio- } \\
\text { pia }\end{array}\end{array}$} & \multirow{2}{*}{$\begin{array}{c}\text { West } \\
\text { Africa } \\
\text { Nigeria }\end{array}$} \\
\hline & Botswana & $\begin{array}{l}\text { Mozam- } \\
\text { bique }\end{array}$ & $\begin{array}{l}\text { South } \\
\text { Africa }\end{array}$ & $\begin{array}{l}\text { Zimba- } \\
\text { bwe }\end{array}$ & & \\
\hline 2005 population (million) & $1 \cdot 8$ & $20 \cdot 5$ & $47 \cdot 9$ & 13.1 & 79 & $141 \cdot 4$ \\
\hline $\begin{array}{l}\text { Gross domestic product per capita } \\
\text { (US\$) }\end{array}$ & 12,387 & 1,242 & 11,110 & 2,038 & 1,055 & 1,128 \\
\hline Human development index & $0 \cdot 654$ & $0 \cdot 384$ & $0 \cdot 674$ & 0.513 & $0 \cdot 406$ & $0 \cdot 470$ \\
\hline Human poverty index (\%) & $31 \cdot 4$ & $50 \cdot 6$ & $23 \cdot 5$ & $40 \cdot 3$ & $54 \cdot 9$ & $37 \cdot 3$ \\
\hline $\begin{array}{l}\% \text { of population below the poverty- } \\
\text { line (US\$ } 1 \text { per day) }\end{array}$ & 28 & $36 \cdot 2$ & $10 \cdot 7$ & $56 \cdot 1$ & 23 & $70 \cdot 8$ \\
\hline Adult literacy rate (\%) & $81 \cdot 2$ & $38 \cdot 7$ & $82 \cdot 4$ & 89.4 & $35 \cdot 9$ & $69 \cdot 1$ \\
\hline$\%$ not using improved water source & 5 & 57 & 12 & 19 & 78 & 52 \\
\hline $\begin{array}{l}\% \text { of children aged less than } 5 \\
\text { years-underweight-for-age }\end{array}$ & 13 & 24 & 12 & 17 & 38 & 29 \\
\hline Life-expectancy at birth & $48 \cdot 1$ & $42 \cdot 8$ & $50 \cdot 8$ & $40 \cdot 9$ & $51 \cdot 8$ & $46 \cdot 5$ \\
\hline $\begin{array}{l}\text { Infant mortality rate (per 1,000 } \\
\text { livebirths) }\end{array}$ & 87 & 100 & 55 & 81 & 109 & 100 \\
\hline $\begin{array}{l}\text { Rate of mortality of children aged less } \\
\text { than } 5 \text { years (per } 1,000 \text { livebirths) }\end{array}$ & 120 & 145 & 68 & 132 & 164 & 194 \\
\hline $\begin{array}{l}\text { Adjusted maternal mortality ratio } \\
\text { (per 100,000 livebirths) }\end{array}$ & 380 & 520 & 400 & 880 & 720 & 1,100 \\
\hline $\begin{array}{l}\% \text { of HIV sero-prevalence (15- } 49 \\
\text { years olds) }\end{array}$ & $24 \cdot 1$ & $16 \cdot 1$ & $18 \cdot 8$ & $20 \cdot 1$ & $0 \cdot 9-3 \cdot 5$ & 3.9 \\
\hline $\begin{array}{l}\text { Public-health expenditure as } \% \text { of } \\
\text { gross domestic product }\end{array}$ & $4 \cdot 0$ & $2 \cdot 7$ & $3 \cdot 5$ & $3 \cdot 5$ & $2 \cdot 7$ & $1 \cdot 4$ \\
\hline $\begin{array}{l}\text { Private health expenditure as } \% \text { of } \\
\text { gross domestic product }\end{array}$ & $2 \cdot 4$ & $1 \cdot 3$ & $5 \cdot 1$ & $4 \cdot 0$ & $2 \cdot 6$ & $3 \cdot 2$ \\
\hline Gini index & $60 \cdot 5$ & $47 \cdot 3$ & $57 \cdot 8$ & $50 \cdot 1$ & $30 \cdot 0$ & $43 \cdot 7$ \\
\hline
\end{tabular}

natural disasters, and persons 'socially excluded' (9). Studies have demonstrated the rapid growth in numbers of urban beneficiaries and the programme effectiveness in reaching the majority of those targeted (27-29). The cash-transfer programme has also contributed to poverty reduction among urban beneficiaries $(27,28)$. However, rural coverage remains poor, and the impact of the programme is unknown.

The South African child support grant (CSG) is an example of a means-tested unconditional social assistance transfer that targets children aged less than 14 years and consists of a monthly grant payable to a primary care giver who is a South African citizen, is a resident in South Africa, and who meets the eligibility criteria (14). More than seven million children benefit from the South African CSG (30). Studies have demonstrated the effectiveness of the grants in addressing the needs of vulnerable children and in reducing poverty. The estimated impact on child poverty in South Africa is significant, with the percentage of children in poverty falling from $43 \%$ to $34 \%$ and the percentage of children living in ultra-poverty falling from 13\% to $4 \%$ (31). The grants also contribute to social cohesion and have a positive impact on the economic opportunities of households (32). Households that receive social grants are more likely to send young children to school, provide better nutrition for children, and have members looking for work more intensively, extensively, and successfully than workers in comparable households without social grants (33).

However, the extent to which these cash-transfer programmes impact on health and well-being in sub-Saharan Africa has been inferred and not measured directly. 


\begin{tabular}{|c|c|c|c|}
\hline Type of policy & Country & Example & Brief description \\
\hline \multirow[t]{3}{*}{ Cash-transfers } & Ethiopia & $\begin{array}{l}\text { Productive } \\
\text { Safety-net } \\
\text { Programme }\end{array}$ & $\begin{array}{l}\text { Consists of labour-intensive public works, i.e. grants to } \\
\text { households whose adults participate in public works sub- } \\
\text { projects and direct support, i.e. grants to households that } \\
\text { are labour-poor and cannot undertake public works }\end{array}$ \\
\hline & Mozambique & $\begin{array}{l}\text { O Instituto } \\
\text { Nacional De } \\
\text { Acção Social }\end{array}$ & $\begin{array}{l}\text { A cash-transfer programme to households or individu- } \\
\text { als meeting certain eligibility criteria. Known as a 'food } \\
\text { subsidy', it is a monthly cash-transfer to extremely } \\
\text { poor citizens to ease the combined negative effects of } \\
\text { war, natural disasters, and the structural adjust- } \\
\text { ment programme }\end{array}$ \\
\hline & South Africa & $\begin{array}{l}\text { Child sup- } \\
\text { port grant }\end{array}$ & $\begin{array}{l}\text { Consists of a monthly amount paid to children from } \\
\text { birth to } 14 \text { years, who meet the eligibility criteria. The } \\
\text { grants are either paid in cash at specified pay-points, or } \\
\text { deposited directly into the primary care giver's bank ac- } \\
\text { count. The primary care giver is any person whotakes } \\
\text { primary responsibility for the daily needs of the child }\end{array}$ \\
\hline \multirow[t]{3}{*}{$\begin{array}{l}\text { Free social } \\
\text { services }\end{array}$} & Mozambique & $\begin{array}{l}\text { Free primary } \\
\text { education }\end{array}$ & Exemption from paying all primary education fees \\
\hline & South Africa & $\begin{array}{l}\text { Free health- } \\
\text { care }\end{array}$ & $\begin{array}{l}\text { No user-fees in primary healthcare facilities. Also in- } \\
\text { cludes free hospital services to children aged less then } \\
14 \text { years, pregnant women, pensioners, persons re- } \\
\text { ceiving social grants, and the formally unemployed; } \\
\text { tuberculosis services; HIV voluntary counselling and } \\
\text { testing; prevention of mother-to-child transmission of } \\
\text { HIV; cervical screening at clinics; medico-legal servic- } \\
\text { es for sexual assault survivors; and free healthcare for } \\
\text { people with disabilities. Pregnant women and children } \\
\text { covered by private medical insurance and/or living } \\
\text { in households with an income of more than } 100,000 \\
\text { South African Rands (about US\$ } 10,000 \text { ) per year are } \\
\text { not eligible for free hospital care }\end{array}$ \\
\hline & Zimbabwe & $\begin{array}{l}\text { Basic } \\
\text { Education } \\
\text { Assistance } \\
\text { Module } \\
\text { (BEAM) }\end{array}$ & $\begin{array}{l}\text { A component of the Government's wider social protec- } \\
\text { tion strategy, BEAM consists of a national school-fee } \\
\text { assistance programme that provides tuition, levy and } \\
\text { examination fee assistance, targeting children who } \\
\text { have never been to school or who have dropped out of } \\
\text { school or are likely to do so due to a lack of funds }\end{array}$ \\
\hline \multirow{3}{*}{$\begin{array}{l}\text { Institutional } \\
\text { arrangements } \\
\text { to ensure } \\
\text { integration } \\
\text { and improved } \\
\text { effectiveness }\end{array}$} & Botswana & Diphalana & $\begin{array}{l}\text { An integrated programme to address school-girl preg- } \\
\text { nancy across health, education and social welfare sec- } \\
\text { tors, and part of national policies directed at improv- } \\
\text { ing the situation of pregnant school-girls }\end{array}$ \\
\hline & $\begin{array}{l}\text { Gauteng } \\
\text { province in } \\
\text { South Africa }\end{array}$ & $\begin{array}{l}\text { Bana Pele } \\
\text { (Children } \\
\text { first) }\end{array}$ & $\begin{array}{l}\text { Conceptualized as a pro-poor, comprehensive and in- } \\
\text { tegrated package of free services aimed at vulnerable } \\
\text { children with one referral form and access from various } \\
\text { entry-points, such as clinics, schools, and social welfare } \\
\text { services }\end{array}$ \\
\hline & Nigeria & $\begin{array}{l}\text { National } \\
\text { Poverty } \\
\text { Eradication } \\
\text { Programme }\end{array}$ & $\begin{array}{l}\text { A coordination mechanism to ensure that the core } \\
\text { poverty-eradication ministries are effective and with } \\
\text { the overall aim of spearheading the Government's } \\
\text { ambitious programme of eradicating absolute poverty } \\
\text { among Nigerians }\end{array}$ \\
\hline
\end{tabular}




\section{Free social services}

Following the 2004 poverty and social impact analysis in Mozambique to determine the impact of direct costs and opportunity costs on enrollment and retention of pupils in primary education, particularly among the poorest children, all primary education fees were abolished since the 2005 academic year (15). The country has experienced a 20percent increase in enrollment in primary school, which may reflect the abolition of primary schoolfees (34).

In South Africa, free healthcare refers to health services that are rendered free at the point of contact at public-sector clinics, community health centres, and hospitals (16). The policy, implemented in 1994, remains in force. Free healthcare services include all primary healthcare services at clinics and health centres. It also includes free hospital services to children aged less than 14 years, pregnant women, pensioners, persons receiving social grants, and the formally unemployed; tuberculosis services; HIV voluntary counselling and testing; prevention of mother-to-child transmission of HIV; cervical screening at primary healthcare services; and medico-legal services for survivors of sexual assault and people with disabilities.

Pregnant women and children covered by private medical insurance and/or living in households with an income of more than 100,000 South African Rands (about US\$ 10,000) per year are not eligible for free healthcare.

A formal evaluation of the South African free healthcare policy found that the policy has been effective in removing financial access barriers, especially for rural people, informal settlements, and on white-owned farms (35). The free healthcare policy has resulted in increased service-use, particularly for preventive services, such as family planning and antenatal care (36).

In Zimbabwe, the Basic Education Assistance Module (BEAM) was launched in January 2001 as one component of the Enhanced Social Protection Project (ESPP). The main development objective of the BEAM is to prevent irreversible welfare losses for poor households who resort to extreme coping mechanisms, such as withdrawing children from school in response to increasing poverty. It is a national school-fee assistance programme targeting vulnerable children of school-going age (619 years), implemented by the Ministry of Public Service, Labour and Social Welfare in conjunction with the Ministry of Education for sports and culture (17).

The BEAM has assisted nearly one million vulnerable pupils, representing $27 \%$ of school enrollment (17). Communities participated in the selection of BEAM beneficiaries through school selection communities, and the list of selected students was published, thereby enhancing transparency and accountability (17).

This appraisal shows an association between free social service policies and increased service-use. Free healthcare policies have been effective in removing some access barriers but have not had a detectable impact on health status. Although there is generally an inverse relationship between the education level and the burden of infectious diseases, the broader policy impact of free education on health status or health inequities is not known.

\section{INSTITUTIONAL ARRANGEMENTS TO MAXIMIZE POLICY IMPACT}

In response to high rates of teenage pregnancy in Botswana and the legislative requirement that pregnant girls withdraw from school upon knowledge of the pregnancy, Diphalana was conceived as an integrated programme to address school-girl pregnancy across health, education, and social welfare and to reduce social exclusion suffered by teenage mothers (37). The project that started in 1996, was intended to: provide uninterrupted basic education for targeted girls by helping to reduce first and repeated pregnancies; ensure that students who do become pregnant complete school; and improve the scholastic performance of teenage mothers $(19,37)$.

Diphalana was only implemented at a pilot school (19). Pregnant girls were allowed to remain at the pilot school until late in their pregnancy and return to the same school soon after the end of pregnancy. There was a reduction in the number of teenage pregnancies at the pilot school, and most girls returned to the school after the end of their pregnancy. Their achievement was approximately at the level they would have attained without their pregnancy leave (38).

The Bana Pele programme, meaning 'children first', was conceptualized as a pro-poor, comprehensive and integrated package of free services aimed at vulnerable children in Gauteng province, South Africa and commenced in 2005 (18). Through this initiative, the provincial government intends to 
give practical effect to the constitutional rights of children to education, adequate nutrition, shelter, peace, good health, and protection from poverty and disease (18). It includes access to the CSG, free primary healthcare services at clinics and hospitals, free school-uniforms, exemptions from school-fees, the school feeding scheme, and scholar transport (18). The Bana Pele programme reported almost two million beneficiaries, and improved access to CSGs, free health services, free school-uniforms, exemptions of school-fees, the school feeding scheme, and scholar transport (18). At the time of appraisal, a formal impact assessment of the programme had not been done.

The National Poverty Eradication Programme (NAPEP) of Nigeria is a coordination facility to ensure that the core poverty-eradication ministries are effective (20). It commenced in 2002 with the overall aim of spearheading the Government's ambitious programme for eradicating absolute poverty in Nigeria. Absolute poverty was defined as a condition in which a person or a group of persons is unable to satisfy their most basic requirements for survival in terms of food, clothing, shelter, health, transport, education, and recreation. The NAPEP in Nigeria was successful in establishing nationwide structures, and thousands of young people have benefited from training and from the mandatory attachment programme (20). Its emphasis on infrastructure development and social services programmes was also welcomed $(20,39)$.

Table 3 summarizes results of appraisal of the policies and potential impact on health.

In returning to our section heading of whether social inclusion policies are a remedy for health inequalities or a paradox, we conclude that the policies appraised have yielded some positive results. These include improved coverage, improved nutrition intake, poverty alleviation among the beneficiaries, increased service-use, and improved household economic opportunities. However, monitoring systems for most policies are either weak or non-existent; indicators are poorly defined and often neglect to measure system responsiveness; there is often no baseline information on health inequalities within countries; the policies have not been in existence for a long period, and the impact of many policies has not been formally evaluated. Hence, there is insufficient evidence to conclude on whether and/or what the impact of the policies has been on health inequalities.

\section{GOOD POLICIES, WEAK IMPLEMENTATION?}

\section{Cash-transfers}

In Ethiopia, challenges of implementation associated with cash-transfer programmes include the targeting criteria; inappropriate guidelines on the direct support and public works programme; insufficient participation of the community, particularly of women; inadequate monitoring; and a weak mechanism of rapid response $(25,26)$.

In Mozambique, challenges of implementation include uneven regional implementation and administrative capacity; 'leakage' to the non-poor; substantial latent costs of enforcing means-testing; lax enforcement of some eligibility criteria; and poor rural coverage $(28,29)$.

In South Africa, the implementation and administration of social grants was devolved initially to the provinces. A government review identified a number of problems, including provincial inequities, fraud, delays in approving grant applications, and difficulties in accessing payment (33). Consequently, in 2004, the South African Social Security Agency was established to implement and administer social grants (33). Research to examine the allegations that the grants have perverse incentives, one of which is to encourage women and especially teenagers to have more children, has been inconclusive (40).

\section{Free social services}

In Mozambique, the impact of the abolition of primary school-fees has not been formally evaluated. Retention of pupils also depends on the ability of households to meet additional expenses to cover school supplies, uniforms, and textbooks, or an increase in public expenditure to cover these expenses. Global education monitoring reports have noted the inequitable public-education spending in Mozambique, both geographically and among income groups, with the poorest $50 \%$ benefiting from only $35 \%$ of upper primary spending and only 19\% of post-primary spending (34).

In South Africa, the general feeling among publichealth professionals towards free healthcare policy was negative, and they were of the opinion that free healthcare had aggravated existing health service problems, such as poor working conditions, a shortage of medicines, overcrowding, and poor staff morale (35). They were also dissatisfied due to inadequate consultation with them regarding policy 


\begin{tabular}{|c|c|c|c|c|c|c|}
\hline $\begin{array}{l}\text { Policy } \\
\text { category }\end{array}$ & $\begin{array}{l}\text { Country of } \\
\text { operation and } \\
\text { policy/action }\end{array}$ & $\begin{array}{l}\text { Policy } \\
\text { intention or } \\
\text { objectives }\end{array}$ & $\begin{array}{l}\text { Target popula- } \\
\text { tion }\end{array}$ & $\begin{array}{l}\text { Year com- } \\
\text { menced }\end{array}$ & Benefits & $\begin{array}{l}\text { Impact on } \\
\text { health or } \\
\text { health in- } \\
\text { equalities }\end{array}$ \\
\hline \multirow[t]{3}{*}{$\begin{array}{l}\text { Cash- } \\
\text { transfers }\end{array}$} & $\begin{array}{l}\text { Ethiopia's } \\
\text { Productive } \\
\text { Safety Net } \\
\text { Programme }\end{array}$ & $\begin{array}{l}\text { Reduce } \\
\text { vulnerabi- } \\
\text { lity and } \\
\text { attain food } \\
\text { security for } \\
5-6 \text { million } \\
\text { chronically } \\
\text { food-inse- } \\
\text { cure people } \\
\text { by } 2009\end{array}$ & $\begin{array}{l}\text { Vulnerable } \\
\text { women and } \\
\text { children } \\
\text { Elderly house- } \\
\text { holds, other } \\
\text { labour-poor, } \\
\text { high-risk } \\
\text { households } \\
\text { with sick } \\
\text { individuals }\end{array}$ & 2005 & $\begin{array}{l}\text { Improved } \\
\text { nutrition } \\
\text { intake } \\
\text { Avoid food- } \\
\text { selling for } \\
\text { medicines or } \\
\text { school-fees } \\
\text { Invest- } \\
\text { ment in } \\
\text { household } \\
\text { livelihood } \\
\text { activities }\end{array}$ & $\begin{array}{l}\text { Not meas- } \\
\text { ured }\end{array}$ \\
\hline & $\begin{array}{l}\text { Mozam- } \\
\text { bique's INAS } \\
\text { cash-transfer } \\
\text { programme }\end{array}$ & $\begin{array}{l}\text { Social assist- } \\
\text { ance safety- } \\
\text { net aimed } \\
\text { at reducing } \\
\text { absolute } \\
\text { poverty }\end{array}$ & $\begin{array}{l}\text { Vulnerable } \\
\text { women and } \\
\text { children, } \\
\text { elderly and } \\
\text { disabled } \\
\text { people, } \\
\text { socially- } \\
\text { excluded } \\
\text { persons }\end{array}$ & 1990 & $\begin{array}{l}\text { Coverage of } \\
\text { urban poor } \\
\text { Poverty } \\
\text { reduction } \\
\text { among ur- } \\
\text { ban benefici- } \\
\text { aries }\end{array}$ & $\begin{array}{l}\text { Not meas- } \\
\text { ured }\end{array}$ \\
\hline & $\begin{array}{l}\text { Child sup- } \\
\text { port grants in } \\
\text { South Africa }\end{array}$ & $\begin{array}{l}\text { Poverty } \\
\text { relief for } \\
\text { vulnerable } \\
\text { children }\end{array}$ & $\begin{array}{l}\text { Children up } \\
\text { to } 14 \text { years }\end{array}$ & 1994/1995 & $\begin{array}{l}\text { Poverty } \\
\text { reduction } \\
\text { Improved } \\
\text { child nutri- } \\
\text { tion intake } \\
\text { Improved } \\
\text { social cohe- } \\
\text { sion } \\
\text { Improved } \\
\text { household } \\
\text { economic } \\
\text { opportuni- } \\
\text { ties }\end{array}$ & $\begin{array}{l}\text { Economet- } \\
\text { ric model- } \\
\text { ling shows } \\
\text { improved } \\
\text { childhood } \\
\text { nutrition } \\
\text { measured } \\
\text { by height- } \\
\text { for-age }\end{array}$ \\
\hline \multirow[t]{2}{*}{$\begin{array}{l}\text { Free } \\
\text { social } \\
\text { services }\end{array}$} & $\begin{array}{l}\text { Mozam- } \\
\text { bique's free } \\
\text { primary edu- } \\
\text { cation policy }\end{array}$ & $\begin{array}{l}\text { Improve } \\
\text { school enroll- } \\
\text { ments and } \\
\text { pupil's reten- } \\
\text { tion rates }\end{array}$ & $\begin{array}{l}\text { Children } \\
\text { in primary } \\
\text { school }\end{array}$ & 2005 & $\begin{array}{l}\text { Increase pri- } \\
\text { mary school } \\
\text { enrollment }\end{array}$ & $\begin{array}{l}\text { Not meas- } \\
\text { ured or } \\
\text { known }\end{array}$ \\
\hline & $\begin{array}{l}\text { South Africa's } \\
\text { free health- } \\
\text { care policy }\end{array}$ & $\begin{array}{l}\text { Increase ac- } \\
\text { cess to care } \\
\text { for pregnant } \\
\text { women, } \\
\text { children, } \\
\text { elderly, and } \\
\text { disabled }\end{array}$ & $\begin{array}{l}\text { Vulnerable } \\
\text { groups, e.g. } \\
\text { women, chil- } \\
\text { dren, users of } \\
\text { public-health } \\
\text { services, the } \\
\text { elderly, disa- } \\
\text { bled }\end{array}$ & $1994 / 1995$ & $\begin{array}{l}\text { Reduced ac- } \\
\text { cess barriers } \\
\text { to health- } \\
\text { care } \\
\text { Increased } \\
\text { service-use }\end{array}$ & $\begin{array}{l}\text { Not } \\
\text { measured/ } \\
\text { unknown }\end{array}$ \\
\hline
\end{tabular}




\begin{tabular}{|c|c|c|c|c|c|c|}
\hline \multicolumn{7}{|c|}{ Table 3-Contd. } \\
\hline & $\begin{array}{l}\text { Zimbabwe's } \\
\text { BEAM }\end{array}$ & $\begin{array}{l}\text { Reduce the } \\
\text { number of } \\
\text { children } \\
\text { dropping } \\
\text { out of, or } \\
\text { not attend- } \\
\text { ing school } \\
\text { because of } \\
\text { economic } \\
\text { hardship }\end{array}$ & $\begin{array}{l}\text { School chil- } \\
\text { dren in both } \\
\text { urban and } \\
\text { rural areas, } \\
\text { who are un- } \\
\text { able to attend } \\
\text { school } \\
\text { because of } \\
\text { economic } \\
\text { hardships }\end{array}$ & 2001 & $\begin{array}{l}\text { Increased } \\
\text { school at- } \\
\text { tendance }\end{array}$ & $\begin{array}{l}\text { Not } \\
\text { measured/ } \\
\text { unknown }\end{array}$ \\
\hline \multirow[t]{3}{*}{$\begin{array}{l}\text { Institu- } \\
\text { tional } \\
\text { arrange- } \\
\text { ment to } \\
\text { ensure } \\
\text { integra- } \\
\text { tion and } \\
\text { improved } \\
\text { effective- } \\
\text { ness }\end{array}$} & $\begin{array}{l}\text { Botswana's } \\
\text { Diphalana } \\
\text { Project }\end{array}$ & $\begin{array}{l}\text { Provide } \\
\text { uninter- } \\
\text { rupted basic } \\
\text { education } \\
\text { for targeted } \\
\text { girls by } \\
\text { helping to } \\
\text { reduce first } \\
\text { and repeated } \\
\text { pregnancies } \\
\text { Ensure that } \\
\text { students } \\
\text { who do } \\
\text { become } \\
\text { pregnant } \\
\text { complete } \\
\text { school, } \\
\text { Improve the } \\
\text { scholastic } \\
\text { performance } \\
\text { of teenage } \\
\text { mothers }\end{array}$ & $\begin{array}{l}\text { Pregnant } \\
\text { teenage girls } \\
\text { and fathers- } \\
\text { to-be }\end{array}$ & 1996 & $\begin{array}{l}\text { Reduction in } \\
\text { the number } \\
\text { of teenage } \\
\text { pregnan- } \\
\text { cies; girls } \\
\text { returned to } \\
\text { schools }\end{array}$ & $\begin{array}{l}\text { Not meas- } \\
\text { ured }\end{array}$ \\
\hline & $\begin{array}{l}\text { Gauteng } \\
\text { province, } \\
\text { South Africa's } \\
\text { Bana Pele } \\
\text { programme }\end{array}$ & $\begin{array}{l}\text { Integrated } \\
\text { and compre- } \\
\text { hensive pro- } \\
\text { poor social } \\
\text { services to } \\
\text { children }\end{array}$ & $\begin{array}{l}\text { Children up } \\
\text { to } 14 \text { years }\end{array}$ & 2005 & $\begin{array}{l}\text { Improved } \\
\text { access to } \\
\text { and use of } \\
\text { existing free } \\
\text { services }\end{array}$ & $\begin{array}{l}\text { Not } \\
\text { measured/ } \\
\text { unknown }\end{array}$ \\
\hline & $\begin{array}{l}\text { Nigeria's Na- } \\
\text { tional Poverty } \\
\text { Eradication } \\
\text { Programme }\end{array}$ & $\begin{array}{l}\text { A coordina- } \\
\text { tion facility } \\
\text { which aims } \\
\text { to spearhead } \\
\text { the Gov- } \\
\text { ernment's } \\
\text { ambitious } \\
\text { programme } \\
\text { of eradicat- } \\
\text { ing absolute } \\
\text { poverty by } \\
2010\end{array}$ & Poor people & 2001 & $\begin{array}{l}\text { Youth train- } \\
\text { ing } \\
\text { Infrastruc- } \\
\text { ture devel- } \\
\text { opment in } \\
\text { rural areas }\end{array}$ & $\begin{array}{l}\text { Not } \\
\text { measured/ } \\
\text { unknown }\end{array}$ \\
\hline
\end{tabular}


design and implementation (35). A 2005 study that explored experiences of primary healthcare nurses in providing free healthcare services found that nurses felt that they were unable to provide adequate services due to increased workload and that there was misuse of services, exacerbated by lack of physical security at clinics (41). Barriers to accessing free healthcare also included long waitingtimes, unavailability of medicines, and rude and unsympathetic health workers (16).

Weakness of the Zimbabwean BEAM programme includes policy design, i.e. the policy content and guidelines. Children cannot be sponsored or supported at mid-year; particularly when school-fees increase drastically; and there is problematic targeting and selection of children (17).

\section{Institutional arrangements}

The Diphalana programme in Botswana was only partially implemented and was seen as a donordriven initiative, with insufficient buy-in from the Ministry of Education and the local community. Cultural context was not taken into account in the design and implementation of the programme. Senior ministry staff raised doubts regarding sustainability and upscaling of the Diphalana and expected the community to keep it going. Members of the community, on the other hand, saw the pilot as a donor-sponsored activity (37).

Challenges of implementation of the Bana Pele programme include a lack of capacity, insufficient resources, and the duplication of efforts. The intention of the programme was to develop a uniform electronic information system that would enable seamless referral across social sector departments (social assistance, education, and health). However, it remains a paper-based information system. The hospitals have not been well-integrated into the referral system, creating many missed opportunities for referrals and for ensuring a safety-net for vulnerable children (42).

In Nigeria, it has been argued that, while the NAPEP is a good initiative, poor management of human and natural resources, bad governance, corruption over many years, and a huge external debt have worsened poverty in the country $(20,39)$. Other challenges include insufficient participation of the community and lack of awareness about the programme among illiterate people $(20,39)$.

\section{CONCLUSION}

In this paper, we have highlighted the overall de- velopment challenges in sub-Saharan Africa and have presented a rapid appraisal of policies, such as cash-transfers, free social services, and institutional arrangements, to ensure integration and improved effectiveness of policy implementation or outcomes. Cross-cutting policy benefits include reduction in financial access barriers to social services (health and education); improved nutrition intake (cash-transfers); poverty alleviation among vulnerable groups, i.e. children, youths, and the rural poor; and improved household economic opportunities. The positive impact of these policies on health status can only be inferred and more research is needed to establish this evidence.

Policy weaknesses or constraints are in their design and implementation. The policy design weaknesses include the targeting criteria, their enforcement, and latent costs (Ethiopia, Mozambique, and Zimbabwe); inadequate participation of the community (Ethiopia and Nigeria); unintended consequences, such as geographical inequity and civil servant resistance (Botswana, Mozambique, Nigeria, and South Africa); and failure to take cultural issues into account (Botswana and Ethiopia). A major weakness of most policies was the lack of a monitoring and evaluation system, with clear indicators that incorporate system responsiveness.

The policy implementation weaknesses include uneven regional implementation with rural areas worst affected (Mozambique, South Africa, and Nigeria); inadequate or poor administrative and implementation capacity (Mozambique, Nigeria, and South Africa); insufficient resources (Mozambique and South Africa); and leakage to the non-poor; problems of fraud, corruption and lack of involvement of civil servants, and exacerbating implementation capacity problems (Mozambique, Nigeria, and South Africa).

Based on the insights gleaned from the appraisal of policies, our following recommendations are directed at sub-Saharan Africa governments and civil society.

Sub-Saharan Africa governments should:

- recognize the importance of health inequalities at the country level and begin a process to measure these as there is a dearth of information on health inequalities within countries.

- pay attention to social policy design: governments should recognize that policies outside the health sector have a major impact on health outcomes and inequalities. While all policies 
and actions should be located within a universal, human rights framework, those based on targeting of particular groups should involve communities in decision-making. The administrative capacity and resources required to enforce the eligibility criteria of the policies/action and an appropriate system of monitoring and evaluation must be in place.

- ensure that the conditions are in place for effective implementation of the policy: The appraisal has highlighted the need to build strong public service systems that guarantee universal access to social services, e.g. healthcare, education, and social protection. Such public services must empower and support the most vulnerable, e.g. children and women, and build an ethos where civil servants (or the implementers) are involved in policy design and are encouraged to take pride in implementation and their contribution to improvements of health outcomes.

- strengthen the monitoring and evaluation systems: ensure that baseline indicators are measured, identify outcome, and impact indicators upfront and ensure that resources are in place to implement the monitoring and evaluation system. Any monitoring and evaluation system must include information and indicators to measure the impact of policies on health and well-being and incorporate the experiences and voices of beneficiaries and communities together with system responsiveness.

- facilitate the involvement of civil society and create and maintain conditions that enable civil society action and ensure that resources are allocated to allow for genuine participation of the community.

\section{Civil Society should:}

- prioritize the reduction of health inequalities in their programme of action in sub-Saharan Africa. Social movements and community actions have been and can be major forces in developing and implementing innovative action for reduction in health inequalities.

- monitor health inequalities and hold governments accountable for commitments made to improve health and reduce health inequalities.

There are encouraging developments in sub-Saharan Africa with governments' commitment to respond to the health challenges facing Africa. These together with the CSDH have set the global stage for determined action to improve global health and reduce unacceptable health inequalities.

\section{ACKNOWLEDGEMENTS}

This work was funded by the World Health Organization (WHO) through Lancaster University. It was undertaken as work for the Social Exclusion Knowledge Network (SEKN) established as part of the WHO's Commission on the Social Determinants of Health (CSDH). The authors have benefited from the interactions with other colleagues in the SEKN. Although the technical report/monograph was published by the South African Human Sciences Research Council (HSRC) Press, this paper was written specifically for the journal, and permission has been obtained from the HSRC press. The views presented in this article are those of the authors and do not necessarily represent the decisions, policy, or views of $\mathrm{WHO}$ or CSDH Commissioners or the SEKN.

\section{REFERENCES}

1. World Health Organization. The health of the people: the African regional health report. Geneva: Regional Office for Africa, World Health Organization, 2006. $196 \mathrm{p}$.

2. United States Agency for International Development. Strategic framework for Africa. Washington, DC: United States Agency for International Development, 2006. 40 p.

3. United Nations Development Programme. Human development report 2007/2008: fighting climate change: human solidarity in a divided world. New York, NY: United Nations Development Programme, 2007. 400 p.

4. World Health Organization. Closing the gap in a generation: health equity through action on the social determinants of health; final report of the Commission on Social Determinants of Health. Geneva: World Health Organization, 2008. 256 p.

5. Labonte R. Social inclusion/exclusion: dancing the dialectic. Health Promot Int 2004;19:115-21.

6. Popay J, Escoral S, Hernandez M, Johnson H, Mathieson J, Rispel L. Understanding and tackling social exclusion: final report to the World Health Organization's Commission on Social Determinants of Health. Lancaster: University of Lancaster, 2008. 36 p. (http:// www.who.int.social_determinants/knowledge_networks/final_reports/en/index.html, accessed on 16 May 2008).

7. Council for the Development and Social Science Research in Africa. Declaration on Africa's development 
challenges and reflections of the new economic partnership for Africa's development (NEPAD). In: Joint Conference on Africa's Development Challenges in the Millennium, Accra, 23-26 April 2002. (http:// www.ifg.org/wssd/cdssr_twn.htm, accessed on 16 May 2007).

8. Commission of the African Union. 2004-2007 plan of action: programmes to speed up integration of the continent. In: Strategic plan of the Commission of the African Union. V. 3. 3 p. (http://ocpa.irmo.hr/ resources/docs/AU_Plan_of_Action_Culture-en.pdf, accessed on 11 June 2007).

9. Mozambique, Republic of. Action plan for the reduction of absolute poverty 2006-2009 (PARPA II). Maputo: Republic of Mozambique, 2006. 203 p.

10. Rispel L, de Sousa C, Molomo B. Rapid appraisal of social inclusion policies in selected sub-Saharan African countries. Cape Town: Human Sciences Research Council Press, 2008. 64 p.

11. Okojie C, Shimeles A. Inequality in sub-Saharan Africa: a synthesis of recent research on the levels, trends, effects and determinants of inequality in its different dimensions. London: Inter-regional Inequality Facility, 2006. 40 p.

12. Ethiopia. Ministry of Agriculture and Rural Development. Productive safety net programme: programme implementation manual. Addis Ababa: Ministry of Agriculture and Rural Development, Government of Ethiopia, 2004:4-6.

13. Regional Hunger and Vulnerability Programme. Food subsidies programme, Mozambique. REBA case study brief number 7, 2007:1-6. (http://www.wahenga.net, accessed on 8 May 2009).

14. Lund F. Changing social policy: the child support grant in South Africa. Cape Town: Human Sciences Research Council Press, 2008:59-79.

15. Valerio A, Bardasi E, Chambal A, Lobo MF. Mozambique school fees and primary school enrolment and retention. In: Coudouel A, Paternostro S, Dani AA, editors. Poverty and social impact analysis of reforms: lessons and examples from implementation. Washington, DC: World Bank, 2006:93-148.

16. Leatt A, Shung-King M, Monson J. Healing inequalities: the free health care policy. In: Monson J, Hall K, Smith C, Shung-King M, editors. South African child gauge 2006. Cape Town: Children's Institute, University of Cape Town, 2006:51-6.

17. Mararike N. Zimbabwe: the basic education assistance module. Johannesburg: Wahenga, 2006. (http://www.wahenga.net/index.php/views/country_update_view/zimbabwe_the_basic_education_assistance_module_beam/, accessed on 5 July 2007).
18. Gauteng Provincial Government. The Bana Pele programme. 2007. 1 p. (http://www.banapele.gpg.gov. za, accessed on 16 March 2007).

19. Chapman DW, Emert H, Coyne B. Evaluation of the African girls' education initiative: country case study. Botswana: United Nations Children's Fund, 2003:1-15.

20. Elumilade DO, Asaolu TO, Adereti SA. Appraising the institutional framework for poverty alleviation programmes in Nigeria. In Res J Fin Econ 2006;3:66-77.

21. Soares FV. Conditional cash transfers: a vaccine against poverty and inequality. Brasilia: International Poverty Centre, 2004;3:1.

22. Soares SSD, Osório RG, Soares FV, Medeiros M, Zepeda E. Conditional cash transfers in Brazil, Chile and Mexico: impacts upon inequality. Brasilia: International Poverty Centre, 2007. 24 p.

23. Lagarde M, Haines A, Palmer N. Conditional cash transfers for improving uptake of health interventions in low and middle income countires: systematic review. JAMA 2007;298:1900-10.

24. Devereux S, Sabates-Wheeler R, Tefera M, Taye H. Ethiopia's Productive Safety Net Programme (PSNP): trends in PSNP transfers within targeted households. Sussex: Institute of Development Studies, 2006:1-42. (http://www.ids.uk, accessed on 10 May 2009).

25. Sharp K, Brown T, Teshome A. Targeting Ethiopia's productive safety net programme. London: Overseas Development Institute, 2006. 110 p.

26. Slater R, Ashley A, Tefera M, Buta M, Esubalew D. PSNP policy, programme and institutional linkages: final report. London: Overseas Development Institute, 2006:1-48.

27. Schubert B. Poverty and poverty alleviation programmes in the urban areas of Mozambique. Habitat Int 1995;19:499-514.

28. Datt G, Payongayong E, Garrett JL, Ruel M. The GAPVU cash transfer program in Mozambique: an assessment. Washington, DC: International Food Policy Research Institute, 1997. 73 p. (FCND discussion paper no. 36).

29. Low JW, Garrett JL, Ginja V. Can cash transfer programs work in resource-poor countries? The experience of Mozambique. Washington, DC: International Food Policy Research Institute, 1999. 91 p. (FCND discussion paper no. 74).

30. Pauw K, Mncube L. Expanding the social security net in South Africa: opportunities, challenges and constraints. Brasilia: International Poverty Centre, 2007. 38 p. (Country study no. 8).

31. Woolard I. Social assistance grants: impact of gov- 
ernment programmes using administrative data sets (second draft). Pretoria: Human Sciences Research Council, 2003. 13 p. (Project 6.2 of the ten year review research programme).

32. Masango D. Social grants are working: study. Pretoria: BuaNews, 2004:1-2. (http://www.southafrica. info/ess_info/sa_glance/social_delivery/update/ socialgrants-report.htm, accessed on 5 July 2007).

33. Inter-Regional Inequality Facility. Social grants: South Africa. London: Overseas Development Institute, 2006. 4 p. (Policy brief no. 1).

34. United Nations Educational, Scientific and Cultural Organization. Education for all by 2015: will we make it? EFA global monitoring report: summary. Paris: United Nations Educational, Scientific and Cultural Organization, 2008. 41 p.

35. McCoy D. Free health care for pregnant women and children under six in South Africa: an impact assessment.. Durban: Health Systems Trust, 1996:1-51.

36. Shung-King M, Mhlanga ER, de Pinho H. The context of maternal and child health. In: Ijumba P, Padarath A, editors. South African health review 2006. Durban: Health Systems Trust, 2006:107-26.
37. Annan K. We the children: meeting the promises of the World Summit for Children. New York, NY: United Nations Children's Fund, 2001:59.

38. United Nations Children's Fund. Changing lives of girls: evaluation of the African Girls' Education Initiative. New York: United Nations Children's Fund, 2004;83-5.

39. Garuba A. Adult education and poverty alleviation programmes in Nigeria: a case for harmonization. Adamawa: Federal College of Yola, 2004.145-50

40. Lund F. Gender and social security in South Africa. Chapter 9. In: Padayachee V, editor. The development decade? Economic and social change in South Africa, 1994-2004. Cape Town: Human Sciences Research Council Press, 2006:165-7.

41. Netshandama VO, Nemathaga L, Shai-Mahoko SN. Experiences of primary health care nurses regarding the provision of free health care services in the northern region of the Limpopo province. Curationis 2005; 28:59-68.

42. Rispel L, Molomo B, Dumela S. South African case study on social exclusion. Pretoria: Human Sciences Research Council, 2009. 56 p. 